\title{
Introduction: COVID-19 and the Law in Africa
}

\author{
Ebenezer Durojaye* \\ University of the Western Cape, Cape Town, South Africa \\ edurojaye@uwc.ac.za
}

\author{
Olivia Lwabukuna** \\ SOAS University of London, London, UK \\ Ol3@soas.ac.uk
}

\section{Lutz Oette***}

SOAS University of London, London, UK

lo8@soas.ac.uk

\section{Sope Williams-Elegbe****}

Stellenbosch University, Stellenbosch, South Africa

sopewe@sun.ac.za

Following its arrival in African countries in February 2020, COVID-19 has severely tested fragile health systems and economies. Since then, it has taken a heavy toll on individual lives and collective wellbeing. In late February 2021, "all 47 countries [in the World Health Organization (WHO) African region] had reported a total of 2,789,965 confirmed cases and 71,204 deaths with case fatality rate of $2.6 \% "{ }^{1}$ With limited availability of vaccines and the spread of variants, the WHO concluded in April 2021 that "the risk associated with further spread of the SARS-CoV-2 VOCs in the African Region is currently assessed as high to very high for the overall population and very high for vulnerable individuals". ${ }^{2}$

The COVID-19 pandemic and the responses to it have generated common challenges and tensions, particularly concerning the relationship between public health measures on the one hand and the need to protect human

\footnotetext{
* Head, Socio-Economic Rights Project, Dullah Omar Institute, University of the Western Cape, South Africa.

** Lecturer, School of Law, SOAS University of London; fellow, Center for Human Rights, Faculty of Law, University of the Free State, South Africa.

*** Director, Centre for Human Rights Law, SOAS University of London.

**** Professor and head, Department of Mercantile Law and deputy director, African Procurement Law Unit, Stellenbosch University, South Africa.

1 WHO "The coronavirus disease 2019 (COVID-19): Strategic preparedness and response plan for the WHO African region" (1 February 2021-31 January 2022, update of 16 April 2021) at 4.

2 Id at 6 (emphasis original).
} 
rights and secure livelihoods on the other. The resort to lockdowns by many African countries to curtail the pandemic jeopardised the protection of human rights, including the rights to life, dignity, liberty, freedom of assembly and privacy. This in turn affected the social and economic well-being of the people. Consequently, the pandemic has deepened inequality in many African countries, pushing vulnerable and marginalized groups further into poverty. ${ }^{3}$ Across Africa, these challenges have played out in distinctive local, national and transnational settings in which developments have been shaped by underlying structural factors and situation-specific dynamics and responses. Law has provided both the framework within which, and a tool with which, a cross-section of actors, particularly governments, have responded to the pandemic. Beyond the national level, sub-regional and regional instruments and institutions have framed arising legal issues, which also form part of international commitments. These relate to various matters, such as intellectual property rights in respect of vaccines, pooled procurement for medicines and the development of standards pertaining to the holding of elections during COVID-19, by the African Commission on Human and Peoples' Rights and through the African Union (AU) Commission's Guidelines on Elections in Africa in the Context of COVID-19 pandemic and other health emergencies. ${ }^{4}$ The question of states' human rights obligations in this regard has been the subject of an advisory opinion by the African Court on Human and Peoples' Rights. ${ }^{5}$

This special issue provides a unique opportunity to reflect on a great many of the themes the Journal of African Law had identified when issuing its call for papers in the early weeks of the pandemic in May 2020. By the nature of the challenges posed by COVID-19, the submissions, and contributions selected, examine a wide array of legal issues at various levels: local, national, transnational, sub-regional and regional, both doctrinally and empirically. They do so, inter alia, by interrogating: the adequacy of legal frameworks; the way governments, the AU and various institutions have responded to the specific challenges resulting from, and associated with, the outbreak of the pandemic; factors influencing compliance; and the emerging case law of national courts. The articles probe how legal concepts and systems have framed responses and

3 See JA Patel et al "Poverty, inequality and COVID-19: The forgotten vulnerable" (2021) 183 Public Health 110.

4 See in particular: "Statement of the African Commission on Human and Peoples' Rights on elections in Africa during the COVID-19 pandemic" (22 July 2020); "Communiqué of the 976th meeting of the African Union Peace and Security Council, on AU guidelines on elections in Africa in the context of the novel coronavirus (COVID-19) pandemic and other public health emergencies" (29 January 2021), para 2.

5 See "Advisory opinion on request no $001 / 2020$ by The Pan African Lawyers Union on the right to participate in the government of one's country in the context of an election held during a public health emergency or a pandemic, such as the COVID-19 crisis" (16 July 2021). 
have been applied, if not transformed, in the context of the pandemic. The outcome of this examination is a fascinating snapshot of emerging legal responses and their legal, policy and governance dimensions.

In the opening article, Babatunde Fagbayibo and Udoka Owie examine the AU's policy responses to the COVID-19 pandemic and the implications for its aspirational superpowers. Their analysis focuses on the African Joint Continental Strategy for COVID-19, the work of two major operational units (the Africa Task Force for Coronavirus and the Africa Centres for Disease Control and Prevention's Incident Management System) and the role of regional economic communities. The authors argue that, " the AU has been able to craft a sound continental response strategy that is matched by concomitant policy actions and processes". In so doing, "[t]he AU's coordinating strategies in combatting the COVID-19 pandemic present instructive pointers for crafting a feasible template for broader supranational ambitions". They also identify a series of challenges. These include the absence of a normative framework to regulate relations between the AU and regional economic communities, the refusal by some member states to comply with the continental agenda on measures, limited human and financial resources for effectively combating the virus, and the inadequacy of national health systems.

Mansha Mohee identifies key lessons from the early COVID-19 experience for electoral governance and human rights amid pandemics in Africa. She provides a study of initial African responses in electoral administration during the pandemic and examines the normative and institutional framework of electoral governance. In an important contribution, she charts key national and regional mitigation efforts to reconcile the conduct of the electoral process with human rights considerations amid infectious disease outbreaks in Africa and explores the human rights impact of measures taken. She concludes that, "[a]n analysis of preliminary responses shows that perennial tactics of political repression and crackdowns on civic space continue to characterize the African electoral landscape, and are further amplified in an environment clouded by the ostensible prioritization of public health concerns".

John Mubangizi explores the impact of the pandemic on vulnerable people in South Africa in the specific context of poverty and inequality. He argues that COVID-19 has had a disproportionate impact on vulnerable groups and that South Africa's legal framework, particularly the Disaster Management Act and the regulations made under it, has proved to be insufficient. Instead, he recommends taking a human rights-based approach based on accountability and transparency, participation, non-discrimination and equality, the empowerment of rights holders and legality. While acknowledging "that the South African government did undertake some of the actions recommended through its policy response to the pandemic by, inter alia, providing social and economic relief measures to mitigate the impact of the pandemic on vulnerable people", he concludes that there is "much room for improvement" through taking a human rights-based approach.

Adebambo Adewopo examines the framework for protecting pharmaceutical patents, which is designed to meet public health challenges such as 
those presented by the COVID-19 pandemic in Nigeria. Exploring the challenges posed by the need to secure access to COVID-19 vaccines, including the need to integrate intellectual property rights with public health policies, he recommends the adoption of a government use provision under the Nigerian Patents and Designs Act. His "article adopts the legal and constitutional right to health, supported by judicial authorities, to reinforce the rational basis for government use in the current COVID-19 public health crisis" and notes that the "indigenous innovative role in bio-medical research and the development space as an important contribution to the global search for the COVID-19 vaccine is a laudable and realizable vision".

Carolien Jacobs, Patrick Milabyo Kyamusugulwa, Rachel Sifa Katembera and Henri Kintuntu examine government measures to contain COVID-19 in the Democratic Republic of the Congo and women's compliance. Their analysis focuses on the sanitary measures taken by the government, drawing on empirical data from the eastern city of Bukavu. They identify several factors contributing to the willingness to comply with COVID-19 related measures, including fear of sanctions, fear of the pandemic and trust in the state or church. They argue that women's attitude to the state has been ambivalent, crediting the latter with the success in containing the virus while also criticising it "for not providing livelihood assistance during the state of emergency." Further, they contend that a successful approach to compliance with COVID-19 containment measures needs to be context-specific, keeping the costs of compliance low, recognizing the important role of churches and health workers, and taking a comprehensive approach, addressing both health and economic hardship.

Mohamed Abdelsalam Babiker examines the impact of COVID-19 on economic and social rights in Sudan in the context of a fragile democratic transition and suspended constitutionalism. He identifies the poor health system and weak legal protection of economic, social and cultural rights, including the impact of emergency measures on these rights, as key factors in the adverse consequences of COVID-19 for vulnerable populations. Further, he argues that the COVID-19 outbreak in Sudan just over a year after the transitional arrangements following Sudan's revolution resulted in a lack of adequate scrutiny of emergency measures, particularly as institutions envisaged to protect rights (such as the Constitutional Court) have not yet been established. In an important finding on the impact of public health emergencies on political transitions, he argues that the outbreak of the pandemic during the transition simultaneously aggravated the impact of COVID-19 and slowed down, if not jeopardised, the implementation of the constitutional declaration and a series of legislative reform and justice measures.

Anél Du Plessis and Felix Dube chart the impact of the COVID-19 pandemic on the housing and basic service delivery crisis in South Africa before examining the protection of persons living in poverty from eviction during the pandemic. Based on an analysis of emergency legislation, relevant government regulations and emerging jurisprudence (through the cases of Community of Hangberg $v$ City of Cape Town and South African Human Rights Commission $v$ 
City of Cape Town), they find that, "[t]he South African government's response to COVID-19, by way of its emergency law and judicial interventions, has shown a remarkable appreciation of the vulnerability of urban dwellers, especially those at risk of being forcibly removed from their dwellings".

Delali Gawu and Richard Mensah examine COVID-19 contact tracing and privacy rights in Ghana by providing a critical analysis of the Establishment of Emergency Communications System Instrument, 2020 (El 63). They set out how the instrument, adopted to aid contact tracing in public health emergencies and which furnishes government with personal data of all subscribers, has generated dissent and raised concerns over unlimited surveillance and a breach of the right to privacy enshrined in the Constitution. Finding that the instrument is contrary to the law, they recommend that it should be revoked and argue that any law to be adopted "must have due regard for the right to privacy of communication by limiting the information requested and obtainable from electronic communication network and service providers, to what is reasonably necessary for contact tracing".

Serges Kamga explores the compatibility of South Africa's Department of Basic Education Directives to reopen schools during the COVID-19 pandemic with the right to inclusive education of learners with disabilities at the primary level. Using the case of Centre for Child Law v Minister of Basic Education (Centre for Child Law) as a lens of analysis, he argues that the "measures adopted to reopen schools did not cater for the return of learners with disabilities who were already excluded when education was moved to online platforms and media in the early stages of lockdown". Consequently, he identifies the need for the government to take reasonable accommodation measures, requiring the government "to take positive steps to provide these persons with individualized materials and other support to enable effective education and maximize academic and social development in a way that is consistent with the goal of 'full inclusion'”.

The contributions invite some observations on the role of law emerging from the first phase of COVID-19 in Africa. First, law has played an important role in both shaping and scrutinising responses to COVID-19, particularly but not exclusively where measures were taken pursuant to emergency declarations and regulations. This applies especially to human rights law. As developments in Ghana, Nigeria, South Africa and Sudan illustrate, human rights law has served to expose shortcomings in the conception and implementation of responses in areas such as electronic communications, adequate provision of livelihoods, patents and inclusive education. In the Africa-wide context, it has done so in respect of the right to participate in government. Conversely, human rights law has, inter alia, protected unlawful occupiers from eviction in South Africa. Secondly, law is a critical factor in the struggle to negotiate and find the right balance between restrictive public health measures to contain COVID-19 on the one hand and their adverse impact on livelihoods, health (other than COVID-19), education etc, on the other. Courts have exercised a crucial function in this regard, as is evident in South Africa and also Sudan, where the absence of a functioning Constitutional Court has been 
identified as a major lacuna. As the case study from the Democratic Republic of the Congo demonstrates, it is equally critical to move beyond the legal sphere to identify the social, economic and cultural factors that determine the extent of compliance with measures aimed at combating COVID-19. A clear finding from this study, and from South Africa and Sudan, is the importance, and difficulty, of adequately addressing economic hardships resulting from public health related restrictions. The third aspect relates to regional and sub-regional governance matters. The AU has, notwithstanding a series of persistent challenges, fulfilled a critical policy and coordinating function in the continent-wide fight against COVID-19. For their part, regional human rights bodies have developed important standards and guidance on pressing issues, such as how best to ensure the right to democratic participation during a pandemic. Fourthly, this list is by necessity incomplete. The scope and ramifications of COVID-19 in relation to the law in Africa is too vast a subject to fit within the present publication. This special issue is therefore one of the many ongoing engagements to grasp and grapple with how COVID-19 has impacted our lives at all levels, including in the field of law. As such, the editors hope that it inspires further scholarship, also on the relationship between epidemics and the law in Africa more broadly, not least to serve the important role of critically examining and guiding us through these challenging times.

In that regard, it is important to recall that Africa has a long history of epidemics, the most outstanding being the HIV/AIDS and Ebola epidemics that preceded and continue to run in parallel to this current, unprecedented COVID-19 pandemic. Legal scholarship on the ground in Africa as well as outside the continent in relation to pertinent issues has not been as widespread or detailed as the evolving scholarship on the COVID-19 pandemic itself. Africa, being the region of the world currently most affected by the HIV/AIDS epidemic, has made important progress but also faces outstanding social, legal and policy challenges that negatively impact addressing the epidemic. Most African countries have adopted legislative, policy or other measures to respond to HIV, which can positively or negatively impact vulnerability to HIV and access to HIV-related services. For instance, some of the laws adopted have faced criticism over human rights and public health concerns. ${ }^{6}$ Legal solutions, including scholarship, can be key to engaging issues raised, including addressing the disabling legal and social environments and human rights violations, and engaging with related laws, national policies and strategies. Some scholarship on HIV and the law in Africa has been undertaken over the years, primarily from specific viewpoints and with reference to

6 PM Eba and H Lim "Reviewing independent access to HIV testing, counselling and treatment for adolescents in HIV-specific laws in sub-Saharan Africa: Implications for the HIV response" (2017) 20 Journal of the International AIDS Society 1; PM Eba "HIV-specific legislation in sub-Saharan Africa: A comprehensive human rights analysis" (2015) 15 African Human Rights Law Journal 224. 
some regions and / or countries. ${ }^{7}$ There has also been huge interest and engagement from a human rights perspective, which has largely been driven by non-legal academics looking to explore opportunities within rights-based responses, while embracing more quantitative and data-driven approaches. ${ }^{8}$

Scholarship in relation to the outbreak of the Ebola epidemic and the law in Africa has on the other hand been limited. Aspects of scholarly interrogation are limited to discussing it within the context of emerging infectious diseases, global governance, public / global health or human security. ${ }^{9}$ There has also been some human rights scholarship, specifically looking at sexual and gender based violence, or the tension between human rights and public health. Yet most work is about managing the Ebola epidemic (legalizing coercive quarantine with questionable ethical foundations), comparing its outbreak in Africa to other outbreaks globally, without situating it within the legal, social or health systems contexts within which it evolved in Africa. ${ }^{10}$ Most of

7 AU ACHPR/Res.290 (EXT OS/XVI) 2014, adopted by the African Commission on Human and Peoples' Rights (July 2014), mandated such studies; AIDS and Human Rights Research Unit Compendium of Key Documents Relating to Human Rights and HIV in Eastern and Southern Africa (2008, Pretoria University Law Press); RO Sarumi and AE Strode "Using international law to protect children affected by HIV/AIDS in South Africa: An audit of HIV/AIDS-specific international standards relevant to children affected by HIV/AIDS" (2017) 25/1 African Journal of International and Comparative Law 114; L Ferguson et al "Assessing changes in HIV-related legal and policy environments: Lessons learned from a multi-country evaluation” (2018) 13/2 PLoS ONE 1; A Hagopian et al "Anti-homosexual legislation and HIV-related stigma in African nations: What has been the role of PEPFAR?" (2017) 10/1 Global Health Action 1; N Bruhn "Litigating against an epidemic: HIV/AIDS and the promise of socioeconomic rights in South Africa" (2011) 17 Michigan Journal of Race and Law 181; F Viljoen and S Precious Human Rights under Threat: Four Perspectives on HIV, AIDS and the Law in Southern Africa (2007, Pretoria University Law Press); E Durojaye Litigating the Right to Health in Africa: Challenges and Prospects (2016, Routledge). Of note is the huge amount of scholarship undertaken in or on South Africa.

8 Issues relating to women and girls, children, displaced populations, migrants and refugees, indigenous peoples, LGBTIQ communities and sex workers, and prisoners, are key areas of scholarship with which there can be deeper engagement from various legal viewpoints.

9 G Burci "Ebola, the Security Council and the securitisation of public health" (2014) 10 Questions of International Law 27; M Sinha and W Parmet "The perils of panic: Ebola, HIV and the intersection of global health and law" (2016) 42/2-3 American Journal of Law E Medicine 223; L Gostine "Ebola: Towards an international health systems fund" (2014) 384/9951 The Lancet 49; L Gostin Global Health Law (2014, Harvard University Press); J Hodge et al "Global emergency legal responses to the 2014 Ebola outbreak: Public health and the law" (2014) 42/4 Journal of Law, Medicine E Ethics 595.

10 M O'Brien and MX Tolosa "The effect of the 2014 West Africa Ebola virus disease epidemic on multi-level violence against women" (2016) 9/3 International Journal of Human Rights in Healthcare 151; E Tambo "Non-conventional humanitarian interventions on Ebola outbreak crisis in West Africa: Health, ethics and legal implications" (2014) 3/42 Infectious Diseases of Poverty; P Eba "Ebola and human rights in west Africa" (2014) 384/9960 The Lancet 2091; E Durojaye and G Mirugi-Mukundi "The Ebola virus and human rights concerns in Africa" (2015) 19/3 African Journal of Reproductive Health 18; 
the research has also not been strictly legal and / or concerned with legal and social constructions around it and / or interactions on the ground in Africa.

The COVID-19 pandemic, which has been highly regulated and governed through the law, with huge legal implications for everyday lives on the ground in Africa, requires proper engagement through legal scholarship. This can be a way of promoting knowledge on the potential, possibilities and limits of law in times of pandemics / epidemics but can also build a repository on what is being done in Africa, reflect good practices and opportunities to transform Africa's fragile health systems through legal intervention, and possibly offer some lessons for collaborative global health governance. The lessons, both negative and positive, from legal engagement and scholarship on HIV/AIDS and Ebola in Africa will prove important for how legal scholarship on COVID-19 is approached. There are signs that more proactive legal scholarship in this area has already taken off within the African continent and outside it. This special issue constitutes part of these efforts.

contd

C Moore "Ebola, quarantine and the need for a new ethical framework" (2020) 13/9 Journal of Medical Ethics and History of Medicine 1. 